\title{
Copepods grazing on Coscinodiscus wailesii: a question of size?
}

\author{
Sandra Jansen
}

Received: 26 October 2007 / Accepted: 16 April 2008 / Published online: 20 May 2008

(C) Springer-Verlag and AWI 2008

\begin{abstract}
Grazing of female copepods, Acartia clausi and Temora longicornis, on the large centric diatom Coscinodiscus wailesii, was studied in the laboratory. While A. clausi females did not feed on C. wailesii, T. longicornis showed a skilful handling of these large algae. The cells were not completely ingested but copepods bit a small piece out of the silica wall and then ingested the cell content only. Faecal pellet analyses showed little remains of the silica walls, and most of the content could only be classified as undefined matter. Therefore the general analyses of faecal pellets and gut content of copepods from the field must be interpreted with caution.
\end{abstract}

Keywords North Sea $\cdot$ Copepods · Grazing ·

Feeding strategies

\section{Introduction}

Copepods are selective feeders and their mode of feeding has important implications for the structure of pelagic food webs (Kiørboe et al. 1996). The traditional view of copepods as relatively uniform suspension-feeders has been replaced by the recognition that a wide variety of mechanisms exist to detect, pursue, capture and reject prey (Price

Communicated by H.-D. Franke.

S. Jansen $(\bowtie)$

Alfred Wegener Institute for Polar and Marine Research, Am Handelshafen 12, 27570 Bremerhaven, Germany e-mail: Sandra.Jansen@ awi.de
1988). The ability and skill in handling individual food items was mainly discovered by direct video observations (Alcaraz et al. 1980; Koehl and Strickler 1981). The use of passive filtration or active capture of prey is dependent on the prey size grazed upon. The passive feeding mode is used to capture cells which are too small to be individually detected by the copepod. Generally copepods prefer larger food items (Mullin 1963; Paffenhöfer 1988), using the active feeding mode. Hansen et al. (1994) evaluated the assumption of a group-specific size ratio between pelagic predators and their prey on the basis of literature data and suggested an optimum ratio of 18:1 for copepods. When grazing at the upper end of the prey size spectrum, an inefficient feeding behaviour may occur due to sloppy feeding (e.g. Roy et al. 1989) which may strongly impact the food web as increasing amounts of dissolved organic matter are released into the water (Møller 2005).

Coscinodiscus wailesii is the largest diatom species commonly found in the North Sea phytoplankton in recent years (Fig. 1a). Studies on copepod grazing on this diatom are of particular interest because the latter is a non-indigenous species, which from its initial appearance in 1977 in the English Channel has spread and become established within the North Sea in recent years (Edwards et al. 2001). There is evidence, that under certain conditions $C$. wailesii may displace indigenous phytoplankton species and that many native primary consumers find this species unpalatable (Edwards et al. 2001).

The present study gives insights into the individual handling of extremely large diatoms by copepods. Feeding of the common North Sea copepods Acartia clausi and Temora longicornis on the large diatom $C$. wailesii was studied under laboratory condition. Emphasis was on behavioural observations. 
Fig. 1 Micrographs of Coscinodiscus wailesii, the largest diatom commonly found in the North Sea (mean diameter at the time of this study: $380 \mu \mathrm{m}$ ). Micrograph a shows an intact cell, while in b the cell was locally damaged with a needle. In response to this treatment the protoplasma concentrates on the side opposite to the point of damage

\section{Materials and methods}

\section{Phytoplankton collection}

Single cells of $C$. wailesii were isolated from a water sample, taken in April 2005 at the permanent sampling station Helgoland Roads in the North Sea $\left(54^{\circ} 11^{\prime} \mathrm{N}, 7^{\circ} 54^{\prime} \mathrm{E}\right)$. Algae were cultured in F/2 medium (Guillard and Ryther 1962 ) at $15^{\circ} \mathrm{C}$ and L:D 16:8. Cell measurements were made under an inverted microscope (Zeiss Axiovert 200) at $160 \times$ magnification.

\section{Zooplankton collection}

Copepods were collected with a $160 \mu \mathrm{m}$ mesh zooplankton net, in November 2005 at the permanent sampling station Helgoland Roads in the North Sea $\left(54^{\circ} 11^{\prime} \mathrm{N}, 7^{\circ} 54^{\prime} \mathrm{E}\right)$. After retrieval, copepods were diluted in 101 filtered seawater and stored dark at $15^{\circ} \mathrm{C}$ until further handling. Back in the laboratory, copepods were checked and healthy females of the abundant copepods $A$. clausi and $T$. longicornis were picked out for experiments. A. clausi is a small neritic copepod. The monthly mean prosoma length of female $A$. clausi range from 770 to $1,140 \mu \mathrm{m}$ while the length of the cephalothorax of female $T$. longicornis vary between 875 and $1220 \mu \mathrm{m}$, with smaller individuals in the autumn/winter months (Halsband and Hirche 2001). The mean equivalent spherical diameter (ESD) is given with 388 and $612 \mu \mathrm{m}$ for A. clausi and T. longicornis, respectively (Møller 2005).

Animals were kept in a temperature controlled room $\left(15^{\circ} \mathrm{C}\right)$ in 11 glass bottles on a slowly rotating plankton wheel $(60 \mathrm{~cm}$ diameter, $1 \mathrm{rpm})$. Prior to the experiments, the copepods were fed a mixture of Rhodomonas baltica and Thalassiosira weissflogii. Both species were feeding on this mixture and faecal pellets were produced.

\section{Grazing observations}

Acartia clausi and Temora longicornis females were transferred to $100 \mathrm{ml}$ beakers, providing $C$. wailesii in a concentration of $\sim 3$ cells $\mathrm{ml}^{-1}$, equivalent to $\sim 800 \mu \mathrm{g} \mathrm{C}^{-1}$ (Tada et al. 2000). Animals were acclimated to the new food for approximately $24 \mathrm{~h}$. Before starting the grazing observations, the copepods were carefully transferred to new beakers, providing $C$. wailesii in the same concentration as during acclimation. Grazing observations were conducted over a period of several hours with the binocular in a temperature controlled room $\left(15^{\circ} \mathrm{C}\right)$. Handling time was defined as the time from first contact of the copepod with a cell until its ingestion or rejection. Faecal pellets were picked out of the beakers at the end of the observation and examined under an inverted light microscope (Zeiss Axiovert 200) where micrographs were taken (Zeiss Axiocam MRc5).
Fig. 2 Empty Coscinodiscus wailesii cells after grazing by Temora longicornis. Most of the cells show destructions on two opposed sides of the frustule
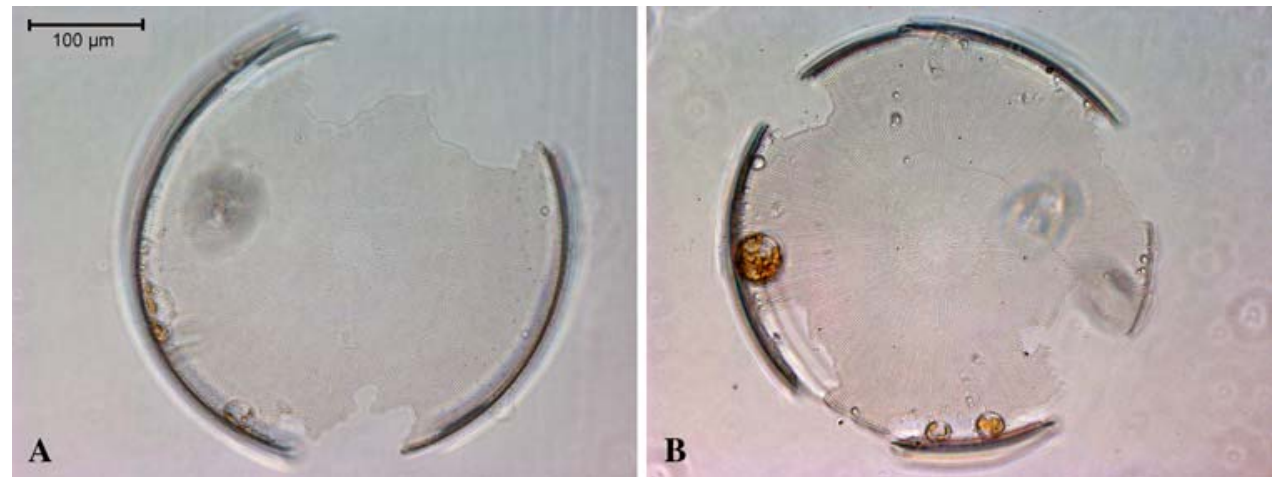


\section{Results and discussion}

At the time of the experiments the cell diameter of $C$. wailesii was $379 \pm 1.5 \mu \mathrm{m}(n=50)$. With an assumed height of this cylindrical-shaped diatom of $190 \mu \mathrm{m}$, the estimated average ESD value was $\sim 345 \mu \mathrm{m}$. Thus, the predator-prey size ratios were $1.1: 1$ and $1.8: 1$ for $A$. clausi and T. longicornis, respectively. Both ratios are extremely low, keeping in mind that the optimum ratio for the body size of copepods to their prey is thought to be $\sim 18: 1$, ranging from $10: 1$ to 30:1 (Hansen et al. 1994). Another indication of the relative sizes of grazers and algae is given by the fact that the diameter of $C$. wailesii represents about $50 \%$ of the cephalothorax length of A. clausi, and $30 \%$ of the body length of $T$. longicornis. The size of the algae is several times larger then the stoma size of both copepod species. Therefore, and due to the stability of diatom frustules, the algae cells cannot be ingested as whole.

Acartia clausi did not graze at all on $C$. wailesii during the present study. Even after several days no grazing took place in the experimental beakers and animals starved. Neither eggs nor faecal pellets were produced by A. clausi. Therefore, all further analyses could only be made for the other copepod species investigated. T. longicornis, in contrast, fed on the large diatom. Within the beakers of T. longicornis, several empty cells were found which showed only small signs of destruction on two (mostly opposed) sides of the cell (Fig. 2). During the direct observation of the feeding technique of the copepods under the binocular, the reason for this pattern of cell destruction became clear. Figure 3, established from microscopical observations, schematically shows the behaviour of $T$. longicornis grazing on a large diatom cell. After capture of the cell, the copepod was able to fix the position of the diatom relative to itself with considerable accuracy (Fig. 3b). When a piece of the frustule is bitten off, the protoplasma, i.e. the nutritious content of the diatom, concentrates on the opposite side of the cell which also occurs when a frustule is broken with a needle (Fig. 1b). During feeding, this happened as soon as the frustule was broken by the mandibles of the copepod (Fig. 3c). T. longicornis then turned the cell with its feeding and locomotory appendages till the concentrated protoplasma was directly adjacent to the mouth (Fig. 3d). The copepod bit again a piece out of the frustule and then could reach and ingest the cell content (Fig. 3e). The empty silica frustule was ultimately rejected. Almost no microscopically visible material digestible for the copepod remained within the diatom shell. The rejected emptied frustules showed a characteristic pattern with mostly two (up to five) parts bitten out of the frustules (Figs. 2, 3f). The handling time ranged from 20 to $259 \mathrm{~s}$ with a mean of $107 \mathrm{~s}$
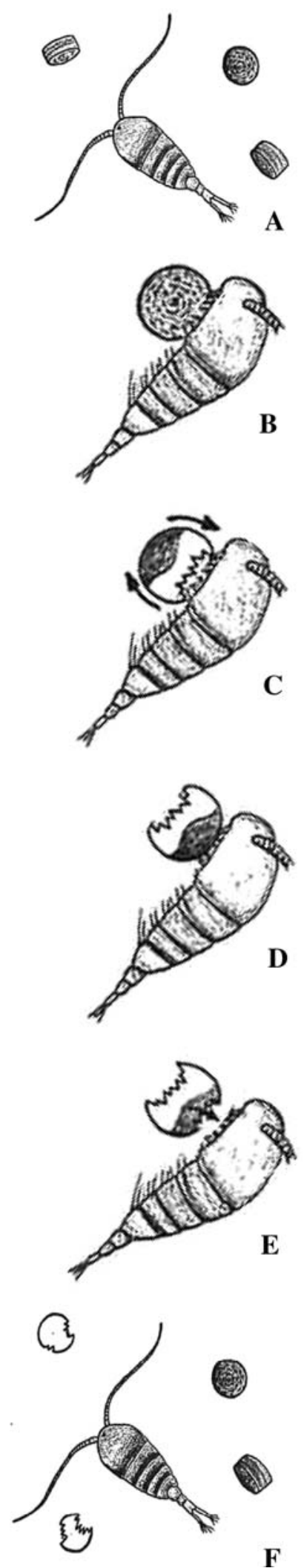

Fig. 3 a-f Schematic diagram of the behaviour of Temora longicornis grazing on Coscinodiscus wailesii. See text for description 
Fig. 4 Light microscope micrographs of faecal pellets produced by $T$. longicornis grazing on a monoculture of Coscinodiscus wailesii. The faecal pellet content consists mainly of brownish unidentifiable matter and only very few pieces of diatom frustules can be identified (arrow)
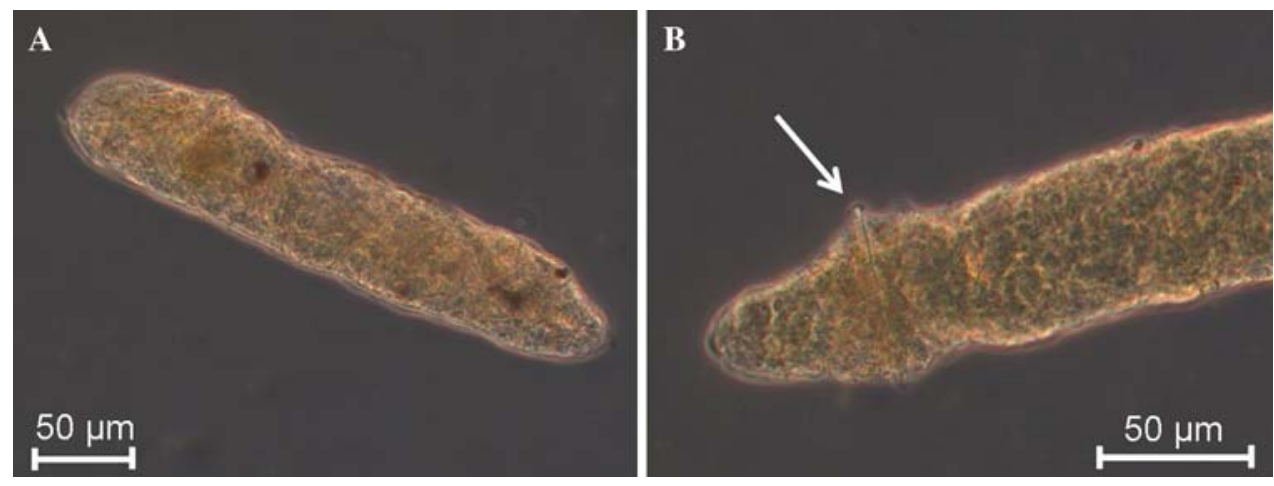

$(n=20)$. Most of the cells caught by T. longicornis were ingested and only few times, the copepod rejected the cell before ingesting the protoplasma, probably due to small disturbances.

While feeding on $C$. wailesii, T. longicornis used its locomotory appendages to fix the large prey item, and therefore was sinking slowly to the bottom of the beaker. When the copepod was disturbed (for instance by moving the beaker), it stopped handling the cell and rejected it in order to escape with a quick jump.

The different behaviour of $A$. clausi and T. longicornis may be explained by the different size of the copepods but also by their different habit. T. longicornis seems to be more robust and it is not surprising, that they can feed on larger and more stable prey items than A. clausi can do. However, it is not clear whether or not $T$. longicornis also grazes on $C$. wailesii when alternative food types are present. In general, diatoms are known to produce chemicals which are thought to impair the reproductive success of copepods (Ianora et al. 2004). The harmful effect of aldehydes on the hatching success of different copepod species has been shown in several laboratory studies (Ban et al. 1997; Ceballos and Ianora 2003; Ianora et al. 2004), and in the field (Miralto et al. 1999; Halsband-Lenk et al. 2005), while other researchers found no negative relationship between the occurrence of diatoms and the copepod hatching success in situ (Irigoien et al. 2002). During the present study, both copepod species produced no eggs, and therefore no observations on hatching success could be made. The fact, that both copepod species investigated produced no eggs during the experiments is not surprising, taking into account that animals were caught in November. During winter months in this region, egg production of $T$. longicornis is very low, while A. clausi is not spawning at all (Halsband and Hirche 2001).

Analyses of gut or faecal pellet contents can give a qualitative insight in what have been grazed by a copepod, but can rarely provide quantitative results (but see Wexels Riser et al. 2003; Jansen et al. 2006). In cases where copepods do not ingest whole cells, interpretation of stomach or faecal pellet contents may be difficult or even impossible as only a few pieces of evidence of the diatom prey may be found. Indeed, faecal pellets of Temora longicornis produced when grazing on $C$. wailesii, look brownish (Fig. 4) and only very few pieces of diatom frustules can be identified under the light microscope (Fig. 4b). Greenish or brownish matter made up the majority of the content of the observed pellets. There are studies reporting that up to $90 \%$ of gut and faecal pellet contents of copepods in the field are made up of brownish or greenish matter. These findings were taken as indication of grazing on detritus or the matter was classified as unidentifiable (Pasternak and SchnackSchiel 2001; Pasternak et al. 2005). However, the present study shows the importance of species-specific observations and the need of new methods to measure grazing. Ideally, it should be possible to directly quantify in situ ingestion of all prey of a single zooplankton by analysis of a freshly caught individual or its faeces, without any prior interference with the food environment (Nejstgaard et al. 2003, 2008). The genetic approach, introduced by Nejstgaard and co-workers seems to be most promising, but is still in its infancy.

Acknowledgement The author would like to thank C. Augustin who kindly provided copepods and algae.

\section{References}

Alcaraz M, Paffenhöfer G-A, Strickler JR (1980) Catching the algae: a first account of visual observations on filter-feeding calanoids. In: Kerfoot WC (ed) Evolution and ecology of zooplankton communities. University Press of New England, Hannover, pp 241-248

Ban S, Burns C, Castel J, Chaudron Y, Christou E, Escribano R, Umani SF, Gasparini S, Ruiz FG, Hoffmeyer M, Ianora A, Kang H-K, Laabir M, Lacoste A, Miralto A, Ning X, Poulet S, Rodriguez V, Runge J, Shi J, Starr M, Uye S, Wang Y (1997) The paradox of diatom-copepod interactions. Mar Ecol Prog Ser 157:287-293

Ceballos S, Ianora A (2003) Different diatoms induce contrasting effects on the reproductive success of the copepod Temora stylifera. J Exp Mar Biol Ecol 294:189-202

Edwards M, John AWG, Johns DG, Reid PC (2001) Case history and persistence of the non-indigenous diatom Coscinodiscus wailesii in the north-east Atlantic. J Mar Biol Assoc UK 81:207-211 
Guillard RRL, Ryther JH (1962) Studies on marine planktonic diatoms Cyclotella nana (Hustedt) and Detonula confervacea (Cleve) Gran. Can J Microbiol 8:229-239

Halsband C, Hirche HJ (2001) Reproductive cycles of dominant calanoid copepods in the North Sea. Mar Ecol Prog Ser 209:219-229

Halsband-Lenk C, Pierson JJ, Leising AW (2005) Reproduction of Pseudocalanus newmani (Copepoda: Calanoida) is deleteriously affected by diatom blooms-a field study. Prog Oceanogr 67:332-348

Hansen B, Bjørnsen PK, Hansen PJ (1994) The size ratio between planktonic predators and their prey. Limnol Oceanogr 39:395403

Ianora A, Miralto A, Poulet SA, Carotenuto Y, Buttino I, Romano G, Casotti R, Pohnert G, Wichard T, Colucci-D’Amato L, Terrazzano G, Smetacek V (2004) Aldehyde suppresion of copepod recruitment in blooms of a ubiquitous planktonic diatom. Nature 429:403-407

Irigoien X, Harris RP, Verheye HM, Joly P, Runge J, Starr M, Pond D, Campbell R, Shreeve R, Ward P, Smith AN, Dam HG, Peterson W, Tirelli V, Koski M, Smith T, Harbour D, Davidson R (2002) Copepod hatching success in marine ecosystems with high diatom concentrations. Nature 419:387-389

Jansen S, Wexels Riser C, Wassmann P, Bathmann U (2006) Copepod feeding behaviour and egg production during a dinoflagellate bloom in the North Sea. Harmful Algae 5:102-112

Kiørboe T, Saiz E, Viitasalo M (1996) Prey switching behaviour in the planktonic copepod Acartia tonsa. Mar Ecol Prog Ser 143:65-75

Koehl MAR, Strickler JR (1981) Copepod feeding currents: food capture at low Reynolds number. Limnol Oceanogr 26:1062-1073

Miralto A, Barone G, Romano G, Poulet SA, Ianora A, Russo GL, Buttino I, Mazzarella G, Laabir M, Cabrini M, Giacobbe MG (1999) The insidious effect of diatoms on copepod reproduction. Nature 402:173-176
Møller EF (2005) Sloppy feeding in marine copepods: prey-sizedependent production of dissolved organic carbon. J Plankton Res 27:27-35

Mullin MM (1963) Some factors affecting the feeding of marine copepods of the genus Calanus. Limnol Oceanogr 8:239-250

Nejstgaard JC, Frischer ME, Raule CL, Gruebel R, Kohlberg K, Verity PG (2003) Molecular detection of algal prey in copepod guts and fecal pellets. Limnol Oceanogr Methods 1:29-38

Nejstgaard JC, Frischer ME, Simonelli P, Troedsson C, Brakel M, Adiyaman F, Sazhin AF, Artigas LF (2008) Quantitative PCR to estimate copepod feeding. Mar Biol 153:565-577

Paffenhöfer G-A (1988) Feeding rates and behaviour of zooplankton. Bull Mar Sci 43:430-445

Pasternak AF, Schnack-Schiel SB (2001) Feeding pattern of dominant Antarctic copepods: an interplay of diapause, selectivity, and availability of food. Hydrobiologia 453/454:25-36

Pasternak A, Wassmann P, Wexels Riser C (2005) Does mesozooplankton respond to episodic $\mathrm{P}$ inputs in the Eastern Mediterranean? Deep Sea Res II Top Stud Oceanogr 52:2975-2989

Price HJ (1988) Feeding mechanisms in marine and freshwater zooplankton. Bull Mar Sci 43:327-343

Roy S, Harris RP, Poulet SA (1989) Inefficient feeding by Calanus helgolandicus and Temora longicornis on Coscinodiscus wailesii: quantitative estimation using chlorophyll-type pigements and effects on dissolved free amino acids. Mar Ecol Progr Ser 52:145-153

Tada K, Pithakpol S, Ichimi K, Montani S (2000) Carbon, nitrogen, phosphorus, and chlorophyll content of the large diatom Coscinodiscus wailesii and its abundance in the Seto Inland Sea, Japan. Fish Sci 3:509-514

Wexels Riser C, Jansen S, Bathmann U, Wassmann P (2003) Grazing of Calanus helgolandicus on Dinophysis norvegica during bloom conditions in the North Sea: evidence from investigations of faecal pellets. Mar Ecol Prog Ser 256:301-304 